\title{
Antitumor activity of silver nanoparticles in Dalton's lymphoma ascites tumor model
}

\author{
This article was published in the following Dove Press journal: \\ International Journal of Nanomedicine \\ 22 September 2010 \\ Number of times this article has been viewed
}

\author{
Muthu Irulappan Sriram \\ Selvaraj Barath Mani Kanth \\ Kalimuthu Kalishwaralal \\ Sangiliyandi Gurunathan \\ Department of Biotechnology, \\ Division of Molecular and Cellular \\ Biology, Kalasalingam University, \\ Tamilnadu, India
}

\begin{abstract}
Nanomedicine concerns the use of precision-engineered nanomaterials to develop novel therapeutic and diagnostic modalities for human use. The present study demonstrates the efficacy of biologically synthesized silver nanoparticles (AgNPs) as an antitumor agent using Dalton's lymphoma ascites (DLA) cell lines in vitro and in vivo. The AgNPs showed dose-dependent cytotoxicity against DLA cells through activation of the caspase 3 enzyme, leading to induction of apoptosis which was further confirmed through resulting nuclear fragmentation. Acute toxicity, ie, convulsions, hyperactivity and chronic toxicity such as increased body weight and abnormal hematologic parameters did not occur. AgNPs significantly increased the survival time in the tumor mouse model by about $50 \%$ in comparison with tumor controls. AgNPs also decreased the volume of ascitic fluid in tumor-bearing mice by $65 \%$, thereby returning body weight to normal. Elevated white blood cell and platelet counts in ascitic fluid from the tumor-bearing mice were brought to near-normal range. Histopathologic analysis of ascitic fluid showed a reduction in DLA cell count in tumor-bearing mice treated with AgNPs. These findings confirm the antitumor properties of AgNPs, and suggest that they may be a cost-effective alternative in the treatment of cancer and angiogenesis-related disorders.
\end{abstract}

Keywords: antitumor, silver nanoparticles, Dalton's lymphoma, ascites

\section{Introduction}

Nanobiotechnology, an emerging field of nanoscience, utilizes nanobased-systems for various biomedical applications. This rapidly developing field of nanoscience has raised the possibility of using therapeutic nanoparticles in the diagnosis and treatment of human cancers. ${ }^{1}$ Nanoscale particles and molecules are a potential alternative for treatment of disease because they have unique biologic effects based on their structure and size, which differ from traditional small-molecule drugs. ${ }^{2}$ In the last few years, several pharmaceutical companies have obtained approval from the US Food and Drug Administration (FDA) for the development of nanotechnology-based drugs. The global market for medical nanotechnology is expected to reach more than \$3 billion within the next five years. ${ }^{3}$ A report based on a study by the European Science Foundation has stated that there is a need for large investment in developing new nanotechnologybased medical tools for diagnostics and therapeutics. ${ }^{2}$

Silver was known only as a metal until the recent advent of the nanotechnology era, when it became recognized that silver could be produced at the nanoscale. Metallic silver has been subjected to recent engineering technologies, resulting in ultrafine particles, the sizes of which are measured in nanometers ( $\mathrm{nm}$ ) and possess distinctive morphologies and characteristics. ${ }^{4,5}$ 
Silver nanoparticles (AgNPs) are among the emerging nanoproducts that have gained increasing interest in the field of nanomedicine due to their unique properties and obvious therapeutic potential in treating a variety of diseases, including retinal neovascularization, ${ }^{6,7}$ and acquired immunodeficiency syndrome due to human immunodeficiency virus (HIV) ${ }^{8,9} \mathrm{AgNPs}$ are also known for their antimicrobial potential against several other viruses, including hepatitis $\mathrm{B},{ }^{10}$ respiratory syncytial virus, ${ }^{11}$ herpes simplex virus type $1,{ }^{12}$ and monkey pox virus. ${ }^{13}$ AgNPs and ions have been shown to possess intrinsic cytotoxic activity ${ }^{14,15}$ and exhibit an enhanced antimicrobial effect when applied on silicon structures. ${ }^{16}$ Silver oxide nanoparticles exhibited antitumor properties in transplanted Pliss lymphosarcoma tumor models when administered by intravenous injection in the form of aqueous dispersions. ${ }^{17}$ Results of microbiologic studies indicate that the interaction of silver ions with molecules of an extracellular lipoprotein matrix increases the permeability of the plasma membrane of microbial cells and eventually causes their death. ${ }^{18}$ AgNPs are synthesized by means of various physical, chemical, and biological methods. Even though the chemical methods involve a very simple procedure, they employ chemical reducing agents, such as citrate, borohydride, or other organic compounds, ${ }^{19,20}$ which are toxic to living organisms and hence render them unsuitable for medical use, whereas ecofriendly biologic synthesis involves formation of AgNPs by means of enzymatic reduction with better control over the shape and size of the nanoparticles.

AgNPs have also become a common component in clothing, food containers, wound dressings, ointments, and implant coatings, ${ }^{21,22}$ and some have already received approval from the FDA..$^{23}$ Silver nanoparticles inhibit vascular endothelial growth factor (VEGF)-induced angiogenesis in bovine retinal endothelial cells. ${ }^{24}$ Similar studies have proven their inhibitory effect on vascular permeability induced by VEGF, interleukin (IL) $-1 \beta,{ }^{25}$ and advanced glycation end product ${ }^{26}$ in retinal endothelial cells. The potent antiangiogenic and antipermeability effects of AgNPs, along with their ability to halt tumor progression in Pliss lymphosarcoma cells, have prompted the study of the antitumor effect of AgNPs in ascitic tumors.

The aim of the present study was to determine the effects of biologically synthesized AgNPs on Dalton's lymphoma ascites (DLA) tumorigenesis under in vitro and in vivo conditions.

\section{Materials and methods Reagents and media}

Streptomycin and penicillin were purchased from Calbiochem (La Jolla, CA). Fetal bovine serum (FBS) was purchased from Sera Laboratories International Ltd (Camarillo, CA). The MTT assay kit was purchased from Roche Diagnostics (Mannheim, Germany). The caspase 3 assay kit was purchased from Sigma (St. Louis, MO). Ischoves Modified Dulbeco's Minimum Essential Medium (IMDM) was purchased from Clonetics $^{\circledR}$ (Walkersville, MD). Tissue culture dishes and 96 well plates were purchased from Falcon ${ }^{\circledR}$ (Franklin Lakes, NJ). Other chemicals were purchased from Sigma (St. Louis, MO) unless otherwise specified.

\section{Cell line}

The DLA cell line was obtained from Amala Cancer Research Institute (Thrissur, India) and was propagated into transplantable tumors in the peritoneal cavity of female Swiss albino mice. The freshly aspirated cells from the mouse peritoneum were washed with phosphate-buffered saline (PBS) under sterile conditions and their concentration was determined using a hemocytometer before transplantation. The aseptically collected ascitic cells were washed with IMDM medium supplemented with FBS $10 \%$, penicillin $100 \mathrm{IU} / \mathrm{mL}$, and streptomycin $100 \mathrm{mg} / \mathrm{mL}$. The harvested DLA cells were incubated in a Petri dish for one hour at $37^{\circ} \mathrm{C}$ in $5 \%$, atmospheric $\mathrm{CO}_{2}$, and nonadherent cells were cultured and used for in vitro experiments.

\section{Biosynthesis and purification of silver nanoparticles}

The synthesis of AgNPs was carried out based on a method described elsewhere. ${ }^{27,28}$ Briefly, the bacterial cells were grown in nutrient broth $(100 \mathrm{~mL})$ containing beef extract ( $1 \mathrm{~g})$, sodium chloride $(0.5 \mathrm{~g})$, and peptone $(1 \mathrm{~g})$ for 24 hours. After incubation, the cells were harvested by centrifugation $(4000 \times \mathrm{g}, 10$ minutes) and washed twice with sterile distilled water. Synthesis of AgNPs was carried out by taking $1 \mathrm{~g}$ of wet Bacillus licheniformis along with $1 \mathrm{mM}$ of $\mathrm{AgNO}_{3}$ and making the reaction mixture up to $50 \mathrm{~mL}$ using deionized water in Erlenmeyer flasks which were then incubated in an incubator shaker at $37^{\circ} \mathrm{C}$ for 24 hours at $200 \mathrm{rpm}$.

Cells from the flasks were washed twice with $50 \mathrm{mM}$ phosphate buffer ( $\mathrm{pH} 7.0$ ) and resuspended in $5 \mathrm{~mL}$ of the same buffer. Ultrasonic disruption of cells was carried out with an ultrasonic processor (Sonics Vibra Cell VC-505/220, Newtown, CT) over three 15-second periods, and with an interval of 45 seconds between periods. The sonicated samples were extracted and the resulting solution was filtered through a $0.22 \mu \mathrm{m}$ Millipore filter to remove cellular debris. The sonicated samples were centrifuged at $16,000 \times \mathrm{g}$ for 30 minutes at room temperature. 


\section{Characterization of silver nanoparticles}

Characterization of the synthesized and purified AgNPs was carried out according to methods described previously. ${ }^{29}$ Samples for transmission electron microscopy (TEM) analysis were prepared on carbon-coated copper TEM grids. TEM measurements were performed on a JEOL model $1200 \mathrm{EX}$ instrument operated at an accelerating voltage of $120 \mathrm{kV}$.

\section{Endotoxin assay}

The Millipore $\mathrm{H}_{2} \mathrm{O}$, used in all our experiments was tested for endotoxins using the gel clot method according to the manufacturer's instructions (LAL endotoxin assay kit). Formation of a gel clot when the sample was treated according to the kit manufacturer's instructions indicated the presence of endotoxin. Similarly, prior to treatment in mice, the nanoparticle suspension in deionized water was checked for possible endotoxin contamination.

\section{Determination of nanoparticle concentration}

Accurate determination of the size and concentration of nanoparticles is essential for the biomedical application of nanoparticles. ${ }^{30}$ The concentration of AgNPs to be administered at a nM level was determined by a method which has been previously reported. ${ }^{31}$ The calculation was as follows:

Initially the average number of atoms per nanoparticles was calculated using the formula:

$$
N=\frac{\pi \rho D^{3}}{6 \mathrm{M}} N_{A}
$$

Where $N=$ number of atoms per nanoparticle, $\pi=3.14$, $\rho=$ density of face-centered cubic silver $=10.5 \mathrm{~g} / \mathrm{cm}^{3}, D=$ average diameter of nanoparticles $=50 \mathrm{~nm}=50 \times 10^{-7} \mathrm{~cm}$, $\mathrm{M}=$ atomic mass of silver $=107.868 \mathrm{~g}, N_{\mathrm{A}}=$ number of atoms per mole (Avogadro's number $\left.=6.023 \times 10^{23}\right)$. Therefore, assuming $100 \%$ conversion of all silver ions to silver nanoparticles:

$$
N=\frac{\left(\pi \times 10.5 \times\left(50.0 \times 10^{-7}\right)^{3} \times 6.023 \times 10^{23}\right)}{6 \times 107.868}
$$

ie, $N=3837233.003$, then the molar concentration of the nanoparticle solution was determined by:

$$
C=\frac{N_{T}}{N V N_{A}}
$$

Where $C=$ molar concentration of the nanoparticle solution, $N_{\mathrm{T}}=$ total number of silver atoms added as $\mathrm{AgNo}_{3}=1 \mathrm{M}, N=$ number of atoms per nanoparticle (from above calculation), $\mathrm{V}=$ volume of the reaction solution in $\mathrm{L}, \mathrm{N}_{\mathrm{A}}=$ Avogadro's number $\left(6.023 \times 10^{23}\right)$

$$
C=\frac{\left[1 \times 6.023 \times 10^{23}\right]}{3837233.003 \times 1 \times 6.023 \times 10^{23}}
$$

Where $\mathrm{C}=2.606 \times 10^{-7} \mathrm{M} / \mathrm{L}=2600 \mathrm{nM} / 10 \mathrm{~mL}$. The required concentrations were thereafter made up from the obtained values.

\section{MTT assay}

The 3-(4, 5-dimethylthiazol-2-yl)-2, 5-diphenyltetrazolium bromide dye reduction assay was performed to determine the cytotoxic effect of the AgNPs at various concentrations. The assay depends on the reduction of MTT by mitochondrial dehydrogenase, an enzyme present in the mitochondria of viable cells, to a blue formazan product. Briefly, the DLA cells were freshly harvested from DLA-bearing mice, and the cell concentration was adjusted to $1 \times 10^{5}$ cells $/ \mathrm{mL}$ and plated onto 96-well flat bottom culture plates with various concentrations of AgNPs. All cultures were incubated for 24 hours at $37^{\circ} \mathrm{C}$ in a humidified incubator. After 24 hours of incubation $\left(37^{\circ} \mathrm{C}\right.$, $5 \% \mathrm{CO}_{2}$ in a humid atmosphere), $10 \mathrm{~mL}$ of MTT $(5 \mathrm{mg} / \mathrm{mL}$ in PBS) was added to each well, and the plate was incubated for a further four hours at $37^{\circ} \mathrm{C}$. The resulting formazan was dissolved in $100 \mathrm{~mL}$ of dissolving buffer (provided as part of the kit) and absorbance of the solution was read at $595 \mathrm{~nm}$ using a scanning Multiwell spectrophotometer (Biorad, Model 680, Japan). All determinations were carried out in triplicate. Concentrations of AgNPs showing 50\% reduction in cell viability (ie, $\mathrm{IC}_{50}$ values) were then calculated.

\section{Caspase 3 assay}

The cells were lysed with the lysis buffer provided in the caspase 3 assay kit (Sigma, St. Louis, MO) and kept on ice for 15-20 minutes. The assay is based on the hydrolysis of the peptide substrate, Ac-DEVD-pNA, by caspase 3, resulting in the release of Ac-DEVD and $p$ nitroaniline (pNA) which absorbs light significantly at $450 \mathrm{~nm}$. Briefly, for $1 \mathrm{~mL}$ of the reaction mixture, $10 \mathrm{~mL}$ of the cell lysate from treated samples was added along with $980 \mathrm{~mL}$ of assay buffer, followed by addition of $10 \mathrm{~mL}$ of $20 \mathrm{mM}$ caspase 3 colorimetric substrate (Ac-DEVD pNA). The cell lysates of the AgNP-treated DLA cells were then incubated at $37^{\circ} \mathrm{C}$ with the caspase 3 substrate for two hours and the absorbance was read at 450 
$\mathrm{nm}$ in a double-beam ultraviolet Vis spectrophotometer (Shimadzu, Japan). The assay was also performed with noninduced cells and in the presence of caspase 3 inhibitor for a comparative analysis.

\section{DNA fragmentation assay}

$1 \times 10^{6}$ cells were lysed in $250 \mu \mathrm{L}$ cell lysis buffer containing $50 \mathrm{mM}$ Tris $\mathrm{HCl}, \mathrm{pH} 8.0,10 \mathrm{mM}$ ethylenediaminetetraacetic acid, $0.1 \mathrm{M} \mathrm{NaCl}$, and $0.5 \%$ sodium dodecyl sulfate. The lysate was incubated with $0.5 \mathrm{mg} / \mathrm{mL}$ RNase $\mathrm{A}$ at $37^{\circ} \mathrm{C}$ for one hour, and then with $0.2 \mathrm{mg} / \mathrm{mL}$ proteinase $\mathrm{K}$ at $50^{\circ} \mathrm{C}$ overnight. Phenol extraction of this mixture was carried out, and DNA in the aqueous phase was precipitated by $25 \mu \mathrm{L}$ (1/10 volume) of $7.5 \mathrm{M}$ ammonium acetate and $250 \mu \mathrm{L}$ (1/1 volume) isopropanol. DNA electrophoresis was performed in a $1 \%$ agarose gel containing $1 \mu \mathrm{g} / \mathrm{mL}$ ethidium bromide at $70 \mathrm{~V}$, and the DNA fragments were visualized by exposing the gel to ultraviolet light, followed by photography.

\section{Animal maintenance and tumor transplantation}

The in vivo studies were conducted on female Swiss albino mice aged 5-6 weeks, weighing $25 \pm 5 \mathrm{~g}$, and housed in polycarbonate cages (five mice per cage) at an ambient temperature of $25 \pm 2{ }^{\circ} \mathrm{C}$ with a 12-hour light and 12-hour dark cycle. The mice were fed with commercially obtained rodent chow and water ad libitum. The animals were allowed to acclimatize to the laboratory environment and were then randomly subjected to the experiment. All the experiments were carried out as per the guidelines of the institutional animal ethics committee (509/01/c/CPCSEA) and had prior approval from the same committee. The DLA cell lines were maintained in mice models by aseptic serial transplantation in Swiss albino mice from tumor-bearing mice after the tenth day of ascites induction.

\section{Experimental design}

The mice were divided into four groups, with six animals in each group: Group 1, blank nontumor mice (nontumor, untreated); Group 2, tumor control mice (tumor induced, untreated); Group 3, tumor-induced mice treated with AgNPs at a concentration of $500 \mathrm{nM}$ in aqueous solution via intraperitoneal (IP) injection for 15 days; and Group 4, AgNPtreated control mice at a concentration of $500 \mathrm{nM}$.

\section{Effect of silver nanoparticles on ascitic tumor}

The minimum inhibitory concentration $\left(\mathrm{IC}_{50}\right)$ determined by MTT assay was used for the in vivo experiments. The AgNP delivered to the mice was carried out using the $\mathrm{IC}_{50}$ obtained. Tumor mice in Group 3 were treated with AgNPs at a concentration of $500 \mathrm{nM}$ for a period of 15 days, and their ability to reduce tumor volume and the number of cells was compared with Group 2 tumor control mice.

\section{Determination of mean survival time and percentage increase in lifespan}

Animals were inoculated with $1 \times 10^{6}$ cells/mouse on day 0, and treatment with AgNPs started 24 hours after transplantation. The control group was treated with the same volume of $0.9 \% \mathrm{NaCl}$ solution. All treatments were given for 15 days. Mean survival time (MST) of each group, consisting of six mice, was noted. The antitumor efficiency of AgNPs was compared with that of 5-fluorouracil (Dabur Pharmaceuticals, India) $20 \mathrm{mg} / \mathrm{kg} /$ day IP for nine days. The MST of the treated groups was compared with that of the control group using the following calculation:

$$
\text { Increase in life span }=(T-C / C) \times 100
$$

where $\mathrm{T}=$ number of days the treated animals survived and $\mathrm{C}=$ number of days the control animals survived.

\section{Euthanasia of experimental animals}

After completion of the experimental treatment, all the mice were deprived of food overnight and euthanized by cervical dislocation under ketamine-xylazine anesthesia. The ascitic fluid and blood samples were collected carefully for various histologic and hematologic estimations, respectively.

\section{Hematologic analysis}

Blood samples were collected by intracardiac puncture following anesthesia with ketamine-xylazine. Whole blood was immediately collected in ethylenediaminetetraacetic-coated vials for examination of potential hematologic toxicity. Hematology analysis included determination of white blood cell, red blood cell, and platelet levels, and measurement of mean corpuscular hemoglobin concentration and volume using an automated hematologic analyzer (MS9 Differential Cell Counter 3 Part, HD Consortium, India).

\section{Histologic analysis}

Ascitic fluid plays a crucial role in DLA and is a collection of pleomorphic cells with hyperchromatic nuclei that are clumps of malignant cells. The viability of tumor cells in ascitic fluid can lead to further aggravation of disease, and hence the morphology and number of cells in ascitic fluid of the controls and tumor-treated mice were observed by 
histologic analysis. The ascitic fluid was carefully collected from the two experimental groups (Group 2 and Group 3) and fixed at a concentration of $1 \mathrm{~mL}$ using a $10 \%$ formalin neutral buffer solution, embedded in paraffin, and cut into sections $5 \mu \mathrm{m}$ thick. The sections were stained using hematoxilyn and eosin, examined under a light microscope, and photomicrographs obtained.

\section{Statistical analysis}

Values were expressed as mean \pm standard deviation (SD). Statistical significance (5\%) was evaluated by one-way analysis of variance (ANOVA) followed by Student's t-test $(P<0.05$, Graph Pad, San Diego, CA $)$.

\section{Results}

\section{Characterization of silver nanoparticles}

Prior to the study of the antitumor effect of AgNPs, characterization of synthesized AgNPs was performed. TEM showed that the purified nanoparticles were spherical with a mean diameter of $50 \mathrm{~nm}$, and the LAL endotoxin assay revealed that the purified AgNPs were endotoxin-free.

\section{Effect of silver nanoparticles on tumor cell viability}

The effect of AgNPs on viability of tumor cells was checked using the MTT assay. The AgNPs were able to reduce viability of the DLA cells in a dose-dependent manner, as shown in Figure 2. After six hours of treatment, the AgNPs were found to be cytotoxic to tumor cells at concentrations of $500 \mathrm{nM}$ and higher. AgNPs at $500 \mathrm{nM}$ decreased the viability of DLA cells to $50 \%$ of the initial level, and this was chosen as the

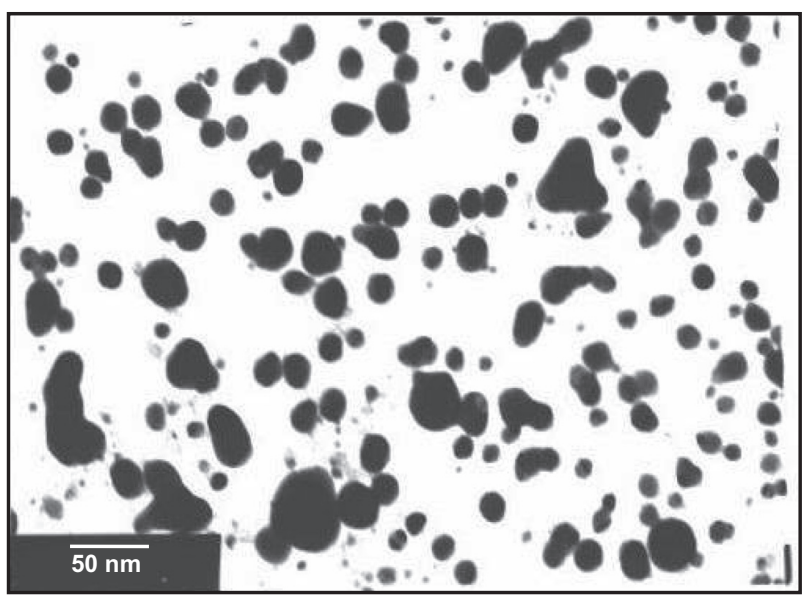

Figure I Transmission electron microscopic image obtained from purified fractions collected after sucrose density gradient of silver nanoparticles synthesized using Bacillus licheniformis. Purified nanoparticles from B. licheniformis were examined by electron microscopy. ${ }^{27,28}$ Several fields were photographed and were used to determine the diameter of nanoparticles. The range of observed diameter was $50 \mathrm{~nm}$.

$\mathrm{IC}_{50}$. Longer exposures resulted in additional toxicity to the cells. These results demonstrate that AgNPs mediate a concentration- and time-dependent increase in toxicity. Because a $500 \mathrm{nM}$ concentration of AgNPs was found to be the $\mathrm{IC}_{50}$, further experiments were carried out using this concentration, to show the effect of AgNPs against the tumor under in vitro and in vivo conditions.

\section{Caspase 3 assay and effect on DNA fragmentation}

Because the cellular metabolic activity seemed affected by the AgNPs, the possibility of apoptosis induction by the nanoparticles was assessed, especially at the $\mathrm{IC}_{50}$. Levels of

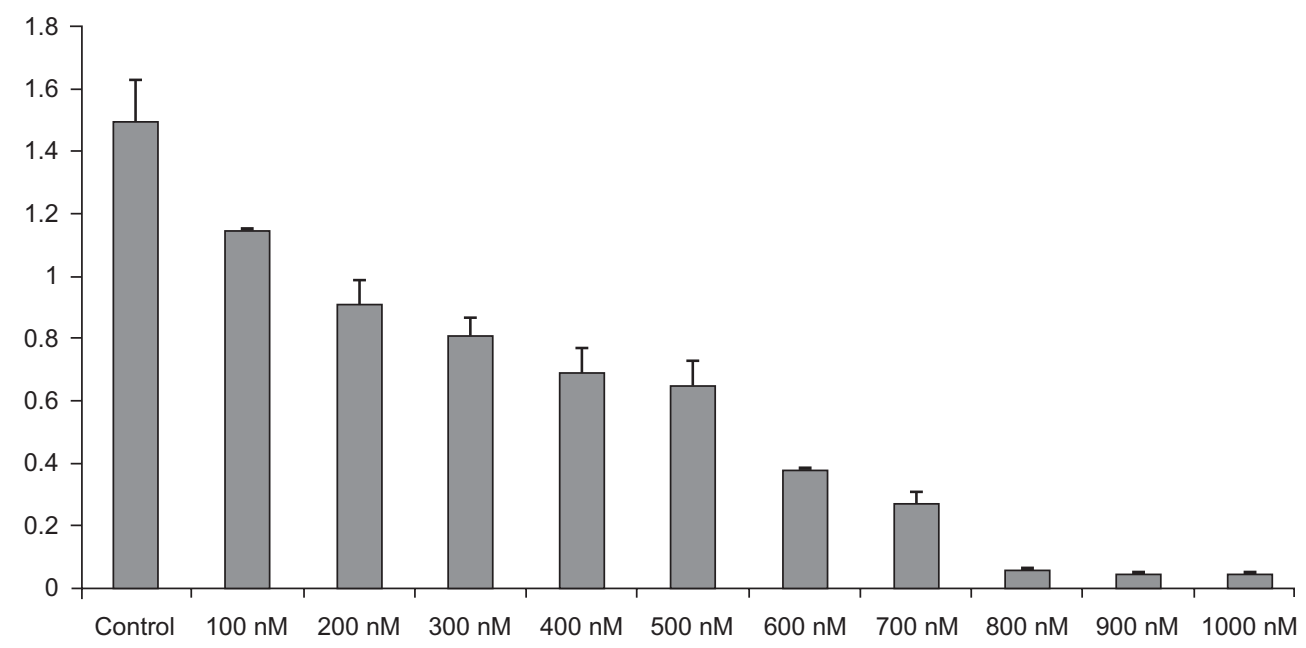

Figure 2 Dose-dependent effect of silver nanoparticles over cell viability using MTT assay. Results are presented in relative units compared with controls. Data represent the mean \pm standard error of the mean of three individual experiments. $P<0.05$ compared with the control group. 
caspase 3, a molecule which plays a key role in the apoptotic pathway of cells, were increased following the treatment with AgNPs, as shown in Figure 3. The cell lysates obtained from DLA cells treated with $50 \mathrm{~nm}$ of AgNPs at $500 \mathrm{nM}$ concentrations for six hours was used for this assay. Caspase 3 activation suggested that AgNPs caused cell death through apoptosis, which was further supported by cellular DNA fragmentation. DNA ladders of the corresponding treated samples confirmed apoptosis (see Figure 4) and showed that the AgNP-treated DLA cells exhibited extensive double strand breaks, thereby yielding a ladder appearance (Lane 3), while the DNA of control DLA cells supplemented with $10 \%$ serum exhibited minimum breakage (Lane 2). The $1 \mathrm{~kb}$ ladder (Lane 1) was used to find the molecular weight of cleaved DNA fragments.

\section{Effect of AgNPs on survival rate in DLA tumor-bearing mice}

The AgNPs confirmed to be endotoxin-free and of size $50 \mathrm{~nm}$ at $500 \mathrm{nM}$ concentration exhibited remarkable anti-DLA activity. Administration of AgNPs IP for 15 days resulted in complete protection in four out of five DLA-challenged mice. Furthermore, the AgNPs prolonged the life span of treated tumor-bearing mice, which survived for 32 days compared with the untreated tumor controls which survived for only 18 days from the first day of tumor induction (Table 1).

\section{Effect of silver nanoparticles on tumor volume and body weight}

Treatment with AgNPs for a period of 15 days in DLA tumorbearing mice led to a significant reduction in tumor volume in comparison with tumor controls. Tumor volume in control mice was about $7.3 \mathrm{~mL}$ but was significantly reduced to $2.6 \mathrm{~mL}$ in the group treated with AgNPs at a concentration of $500 \mathrm{nM}$ for 15 days. Body weight, measured throughout the period of the experiment, was reduced in the treated tumorbearing group when compared with the tumor control group (Table 2). The group of mice treated with AgNPs alone did not exhibit any abnormalities or reduction in body weight.

Figure 6 shows morphologic confirmation of the antitumor activity of AgNPs by significant reduction in tumor volume in the IP region in comparison with the tumor control mice, thereby serving the tumor mice to regain its original weight.

\section{Hematologic analysis}

The mice injected with AgNPs at a concentration of $500 \mathrm{nM}$ for 15 days were examined daily for any changes in morphology and behavior. All the mice survived throughout the experimental period without exhibiting any abnormalities. The mice did not exhibit any symptoms of toxicity, such as fatigue, loss of appetite, change in fur color, or weight loss. Comparative analysis of various hematologic parameters in the AgNP-treated mice and control animals clearly showed that there was no significant alteration except for marginal variations in some parameters that was still within the normal range (Table 3 ).

\section{Histologic analysis of DLA cells}

Histologic analysis of DLA cells from peritoneal fluid revealed that AgNP treatment in tumor-bearing mice led to a significant reduction in the number of malignant cell clumps

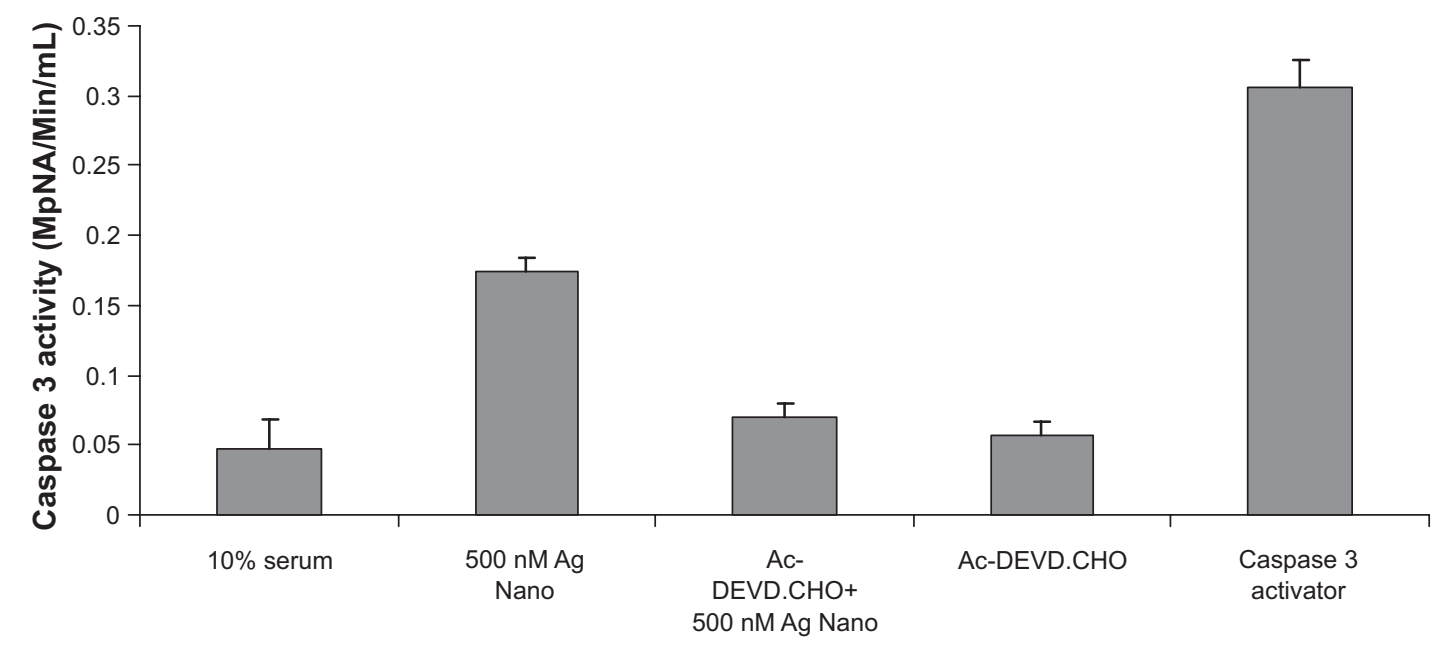

Figure 3 Silver nanoparticles induce apoptosis in Dalton's lymphoma ascites cells by caspase 3 activation.

$* P<0.05$ versus controls, data were mean \pm standard deviation calculated from three individual experiments $(n=3 ; * P<0.0$ I, *** $<0.00 \mathrm{I}, * * * P<0.000 \mathrm{I})$. 


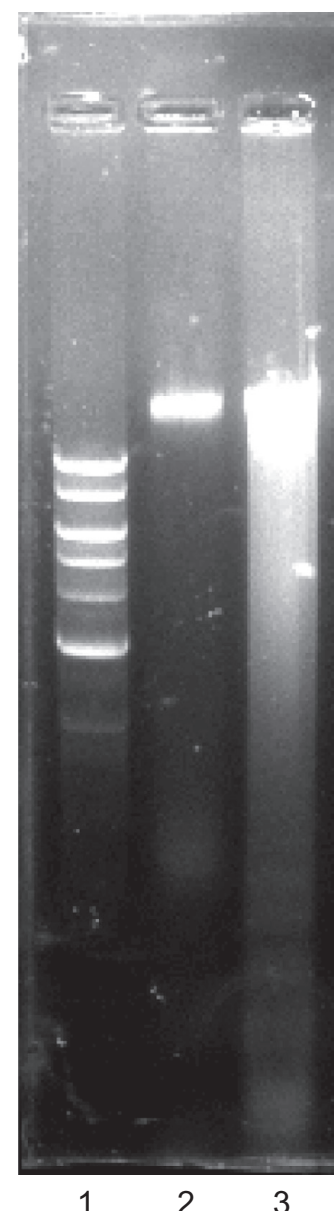

Figure 4 DNA fragmentation assay. Lane I (I kb ladder), lane 2 (I0\% serum), and lane 3 (treated with silver nanoparticles).

for the treated group when compared with the control group (Figure 5), reflecting the potential of AgNPs to have cytotoxic effects in tumor cells, without affecting normal cells.

\section{Discussion}

AgNPs have been shown to have important antiangiogenic properties, ${ }^{32}$ so are attractive for study of their potential antitumor effects. Compounds possessing antiangiogenic

Table I Effect of silver nanoparticles on survival rate in DLA tumor-bearing mice

\begin{tabular}{llll}
\hline $\begin{array}{l}\text { Treatment } \\
\text { group }\end{array}$ & $\begin{array}{l}\text { Design of } \\
\text { treatment }\end{array}$ & $\begin{array}{l}\text { Survival } \\
\text { time (days) }\end{array}$ & $\begin{array}{l}\text { Increase in life } \\
\text { span (T/C, \%) }\end{array}$ \\
\hline $\mathrm{I}$ & Control & $50( \pm 2)$ & - \\
2 & Tumor control & $18( \pm \mathrm{I})$ & - \\
3 & Tumor induced, & $32( \pm 3)$ & 77.78 \\
& treated with AgNPs & & \\
4 & Treated & $50( \pm 5)$ & - \\
& with AgNPs & & \\
\hline
\end{tabular}

Each value represents the mean \pm SD of $n=6$

Abbreviations: AgNPs, silver nanoparticles; DLA, Dalton's lymphoma ascites; SD, standard deviation.
Table 2 Effect of silver nanoparticles on ascitic tumor volume and body weight

\begin{tabular}{llll}
\hline $\begin{array}{l}\text { Treatment } \\
\text { group }\end{array}$ & $\begin{array}{l}\text { Design of } \\
\text { treatment }\end{array}$ & $\begin{array}{l}\text { Tumor } \\
\text { volume } \\
(\mathbf{m L})\end{array}$ & $\begin{array}{l}\text { Average } \\
\text { increase in } \\
\text { body weight }(\mathrm{g})\end{array}$ \\
\hline $\mathrm{I}$ & Control & - & $23.2( \pm \mathrm{I} .6)$ \\
2 & Tumor control & $7.3( \pm \mathrm{I} .5)$ & $42.4( \pm 2.5)$ \\
3 & $\begin{array}{l}\text { Tumor induced, } \\
\text { treated with AgNPs }\end{array}$ & $2.6( \pm 0.5)$ & $29.6( \pm \mathrm{I} .2)$ \\
4 & $\begin{array}{l}\text { Treated } \\
\text { with AgNPs }\end{array}$ & $22.8( \pm 0.5)$ \\
\hline
\end{tabular}

Each value represents the mean $\pm S D$ of $n=6$.

Abbreviations: AgNPs, silver nanoparticles; SD, standard deviation.

properties are known for their potential ability to block the activity of abnormally expressed signaling proteins, such as Ras and Akt, cytokine-based therapies, DNA- or proteinbased vaccines against specific tumor markers, and tyrosine kinase inhibitors which exhibit a consistent antitumor effect. ${ }^{33}$ In this study, AgNPs of size $50 \mathrm{~nm}$ at a concentration of $500 \mathrm{nM}$ had cytotoxic effects on DLA tumor cells under in vitro conditions as well as in an in vivo tumor model.

Initially, a dose-dependent effect of AgNPs on DLA cell lines assessed by MTT assay showed an $\mathrm{IC}_{50}$ value of about $500 \mathrm{nM}$ that induced partial reduction in cell viability in comparison with controls. The cytotoxic effect of AgNPs on cell viability has a major role in antitumor activity, thereby reducing disease progression. This is consistent with the effect of AgNPs on cell viability during VEGFinduced angiogenesis in retinal endothelial cells, ${ }^{34}$ thereby inhibiting the development of angiogenic retinal disorders or

Table 3 Effect on silver nanoparticles on hematologic parameters

\begin{tabular}{|c|c|c|c|}
\hline Parameters & Control & $\begin{array}{l}\text { Tumor } \\
\text { control }\end{array}$ & $\begin{array}{l}\text { Tumor } \\
\text { treated }\end{array}$ \\
\hline $\mathrm{Hb}(\mathrm{g} / \mathrm{dL})$ & II.I $( \pm 0.18)$ & $12.1( \pm 0.37)$ & $11.04( \pm 0.53)$ \\
\hline $\begin{array}{l}\text { RBC distribution } \\
\text { width (\%) }\end{array}$ & $18.8( \pm 2.6)$ & $17.5( \pm 0.9)$ & $19.4( \pm 0.42)$ \\
\hline $\mathrm{MCV}(\mathrm{fL})$ & $47.39( \pm 0.5)$ & $49.6( \pm 2.4)$ & $44.18( \pm 5.3)$ \\
\hline $\mathrm{MCH}(\mathrm{pg})$ & $22.55( \pm 4.26)$ & $16.3( \pm 3.74)$ & $17.85( \pm$ I.54) \\
\hline $\mathrm{MCHC}(\mathrm{g} / \mathrm{dL})$ & $31.16( \pm 1.43)$ & $32.8( \pm 0.67)$ & $34.87( \pm 1.3)$ \\
\hline $\begin{array}{l}\text { Platelet count } \\
\left(\times 10^{9} / \mathrm{L}\right)\end{array}$ & $275( \pm 29.38)$ & $|37|( \pm 2.8)$ & $462( \pm 15.57)$ \\
\hline WBC $\left(\times 10^{9} / L\right)$ & $9.5( \pm 2.37)$ & $58.8( \pm 5.43)$ & $18.17( \pm 6.2)$ \\
\hline $\mathrm{RBC}\left(\times 10^{12} / \mathrm{L}\right)$ & $4.65( \pm 0.56)$ & $7.45( \pm 0.14)$ & $9.34( \pm 1.8)$ \\
\hline $\begin{array}{l}\text { Leukocytes } \\
\left(\times 10^{9} / \mathrm{L}\right)\end{array}$ & $2.82( \pm 0.2 I)$ & $5.42( \pm 2.43)$ & $4.1( \pm 0.87)$ \\
\hline HCT (\%) & $33.17( \pm 2.8)$ & $37.0( \pm 1.26)$ & $29.65( \pm 4.9)$ \\
\hline
\end{tabular}

Each value represents the mean $\pm S D$ of $n=6$.

Abbreviations: $\mathrm{Hb}$, hemoglobin; RBC, red blood cells; MCV, mean corpuscular volume; $\mathrm{MCH}$, mean corpuscular hemoglobin; $\mathrm{MCHC}$, mean corpuscular hemoglobin content; HCT, hematocrit; SD, standard deviation. $P$ values were calculated using one-way analysis of variance followed by Student's t-test by comparison of groups (control versus treatment) and values considered to be significant at $P<0.05$. 
A

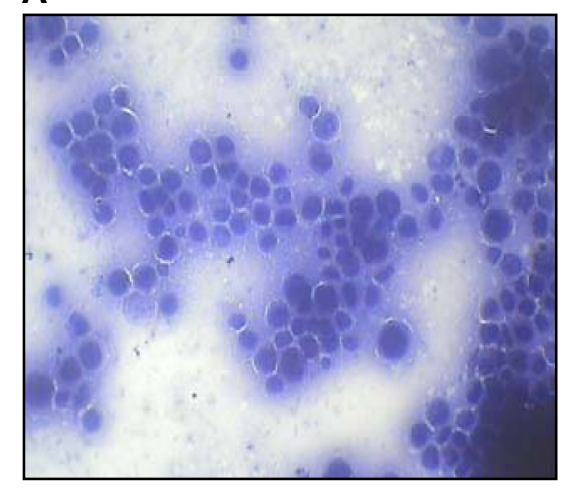

B

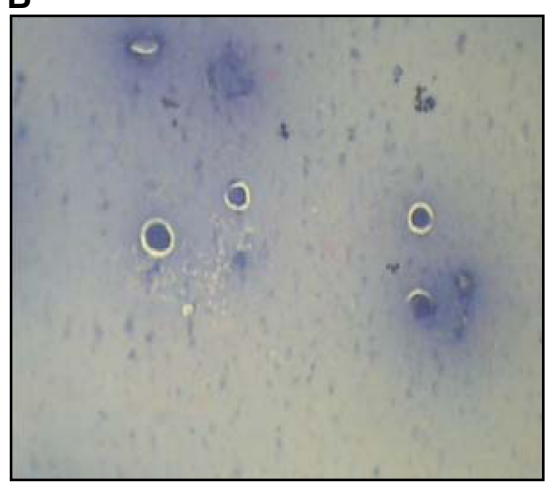

C

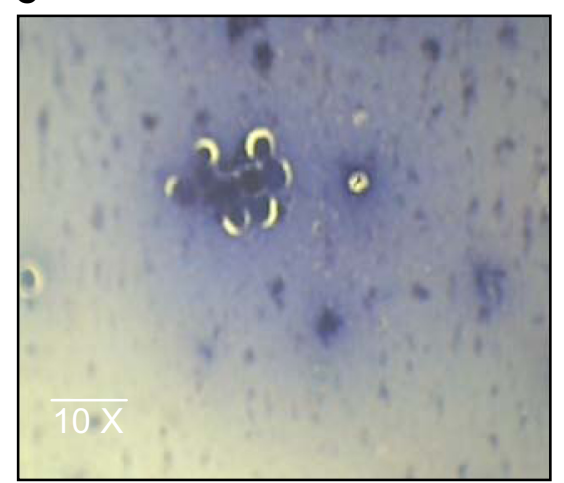

Figure 5 Histologic analysis of ascitic cells in animal models. A) Smear showing numerous clumps of pleomorphic cells with hyperchromatic nuclei that are malignant cell clumps (tumor controls). B and C) Smears show very few pleomorphic cells with hyperchromatic nuclei and significant reduction in malignant cell clumps in comparison with $\mathbf{A}$ (tumor, treated group).

complications. The cytotoxic effects of silver are the result of active physicochemical interaction of silver atoms with the functional groups of intracellular proteins, as well as with the nitrogen bases and phosphate groups in DNA. ${ }^{35}$ In order to clarify the mechanism by which AgNPs exert a cytotoxic effect in tumor cells, a caspase 3 enzyme calorimetric assay was performed which showed that the antitumor activity was mediated by induction of apoptosis activated by the caspase 3 enzyme. The DNA fragmentation experiments subsequently confirmed that induction of apoptosis was triggered by activation of caspase 3 .

The major criteria to be taken into consideration for any potential anticancer drug are its efficacy in prolongation of lifespan and decrease of tumor volume and viable tumor cell

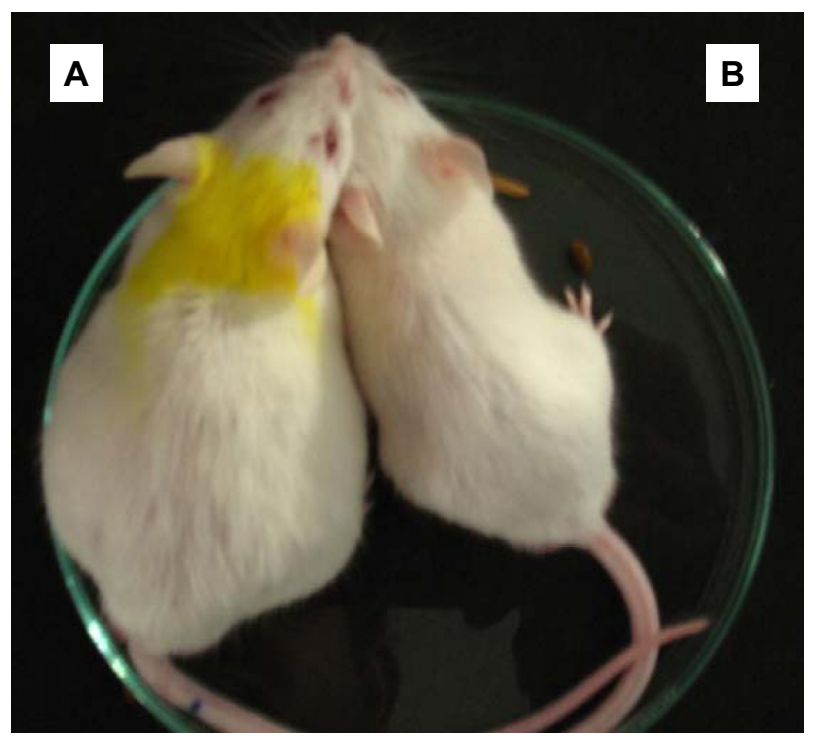

Figure 6 Antitumor activity of silver nanoparticles in a Dalton's lymphoma ascites mice model. A significant reduction in body weight and tumor volume in the peritoneal region following treatment with silver nanoparticles in comparison with controls.

Key: A) tumor control; B) tumor mice treated with silver nanoparticles for 15 days. count. ${ }^{36}$ In the present study, IP inoculation of DLA cells in mice produced a marked increase in the cancer cell count which indicated tumor progression in the animals, whereas a substantial decrease in cancer cell numbers in the treated tumor mice observed through histopathologic analysis clearly showed that AgNPs had a significant inhibitory effect on tumor cell proliferation and survival. The effect of AgNPs in increasing mean survival time and life span (as shown in Table 1) depends on their ability to reduce tumor cell viability and induce cytotoxicity.

The prime feature of tumor development is the escape of cells from programmed cell death due to a metabolic abnormality or genetic mutation. Thus, another criterion for anticancer drug development is the ability of a compound to induce apoptosis in cancer cells. ${ }^{37}$ This ability has been shown for AgNPs in the present study. The increase in tumor weight in Group 2 in our experiment may be due to accumulation of peritoneal fluid given the abnormal enlargement of the peritoneal cavity observed in tumor-bearing mice. Treatment with AgNPs reduced tumor weight and hence increased life span. The hematologic parameters examined in the controls, tumor controls, and tumor-treated mice show the effect of AgNPs in reducing white blood cell and platelet counts in tumor-bearing mice compared with controls. These data highlight the nontoxic effect of AgNPs, which did not induce any alteration in hematologic parameters for treated mice in comparison with controls and, at the same time, led to effective control of white blood cells that possess the immunologic constituents of ascitic fluid.

One feature of DLA tumor growth related to the progression of angiogenic complications is enlargement of the crosssectional area of peritoneal microvessels. The formation of enlarged microvessels early in the course of ascites tumor angiogenesis may relate to the fibrin stroma in which these 
vessels develop. ${ }^{38}$ Tumor cells implanted into the peritoneal cavity secrete vascular permeability factor and thereby render the microvasculature supplying the peritoneal lining tissues hyperpermeable. ${ }^{39} \mathrm{With}$ respect to vascular hyperpermeability, the ascites tumor model used in the present study resembles a solid tumor model, with angiogenesis and generation of a connective tissue stroma. AgNPs that have been proven to delay tumor progression in DLA cell lines and tumor models in vivo may have a potent antipermeability effect by inhibiting tubular formation in growth factor- and advanced glycation end product-induced vascular permeability and cytotoxic effects that inhibit existence of tumor cells, which may be due to their potent activation of the caspase enzyme, as demonstrated in this study. The role of AgNP in inhibiting DLA cell viability and proliferation will be similar to their potential to inhibit the permeability of endothelial cells by inactivating Src kinases which have been proven to have a role in retinal therapies. ${ }^{16}$ The pathways by which AgNPs inhibit the pathway mediating cell proliferation and viability have yet to be explored.

AgNPs serve as antitumor agents by decreasing progressive development of tumor cells. This may be due to their inhibitory activities in several signaling cascades responsible for the development and pathogenesis of the disease which are as yet not understood.

Taken together, our data suggest that AgNPs can induce cytotoxic effects on DLA cells, inhibiting tumor progression and thereby effectively controlling disease progression without toxicity to normal cells.

\section{Conclusion}

It is predicted that nanotechnology will have a $\$ 3.1$ trillion impact on the global economy by $2015 .^{40}$ The projected nanotechnology market is expected to be about US\$25 billion (or $€ 15$ billion) in $2012 .{ }^{41}$ Use of AgNPs should emerge as one of the novel approaches in cancer therapy and, when the molecular mechanism of targeting is better understood, the applications of AgNPs are likely to expand further. ${ }^{42}$ The present study explores the potential antitumor activity of biologically synthesized AgNP in a DLA tumor system in vitro by activation of the caspase 3 enzyme which is known to have a potent inhibitory effect on disease progression in a mouse model, leading to a potent restorative effect in the treated tumor mice near to normal by reducing tumor volume and weight gain. These drug delivery systems are mainly developed according to their ability to differentiate between malignant and nonmalignant cells, making them a promising alternative to existing drugs. This type of targeting efficiency of AgNPs can be accomplished in future therapies using RGD peptide conjugation, which directly targets tumor cells without affecting normal cells. Thus, a study of the exact mechanism by which AgNPs inhibit signaling cascades responsible for the development and progression of the disease would be a tremendous breakthrough in the field of nanomedicine and make these agents an effective alternative in tumor and angiogenesis-related diseases.

\section{Acknowledgments}

Prof G Sangiliyandi was supported by a grant from the Council of Scientific and Industrial Research (CSIR), New Delhi (Project No. 37/0347). The authors gratefully acknowledge Professor Pushpa Viswanathan, WIA Cancer Institute, Chennai, India, for her support in analyzing samples under TEM.

\section{Disclosure}

The authors report no conflict of interest in this research.

\section{References}

1. Yezhelyev MV, Gao X, Xing Y, Hajj AA, Nie S, Regan RMO. Emerging use of nanoparticles in diagnosis and treatment of breast cancer. Lancet Oncol. 2006;7:657-667.

2. Wagner V, Dullaart A, Bock AK, Zweck A. The emerging nanomedicine landscape. Nat Biotechnol. 2006;24:1211-1217.

3. Sahoo SK, Dilnawaz F, Krishnakumar S. Nanotechnology in ocular drug delivery. Drug Discov Today. 2008;13:144-151.

4. Silver S, Phung LT, Silver G. Silver as biocides in burn and wound dressings and bacterial resistance to silver compounds. J Ind Microbiol Biotechnol. 2006;33:627-634.

5. Klasen HJ. Historical review of the use of silver in the treatment of burns. I. Early uses. Burns. 2000;26:117-130.

6. Bhattacharya R, Mukherjee P. Biological properties of "naked" metal nanoparticles. Adv Drug Deliv Rev. 2008;60:1289-1306.

7. Kalishwaralal K, BarathManiKanth S, Pandian SRK, Deepak V, Gurunathan S. Silver nano - a trove for retinal therapies. J Control Release. Mar 29, 2010. [Epub ahead of print].

8. Lara HH, Ayala-Nuñez NV, Ixtepan-Turrent L, Rodriguez-Padilla C. Mode of antiviral action of silver nanoparticles against HIV-1. J Nanobiotechnology. 2010;8:1.

9. Sun RW, Rong C, Chung NPY, Ho CM, Lin CLS, Che CM. Silver nanoparticles fabricated in Hepes buffer exhibit cytoprotective activities toward HIV-1 infected cells. Chem Commun (Camb). 2005;28: 5059-5061.

10. Lu L, Sun RW, Chen R, et al. Silver nanoparticles inhibit hepatitis B virus replication. Antivir Ther. 2008;13:253-262.

11. Sun L, Singh AK, Vig K, Pillai SR, Singh SR. Silver nanoparticles inhibit replication of respiratory syncytial virus. J Biomed Biotechnol. 2008;4:149-158.

12. Baram-Pinto D, Shukla S, Perkas N, Gedanken A, Sarid R. Inhibition of herpes simplex virus type 1 infection by silver nanoparticles capped with mercapto ethane sulfonate. Bioconjug Chem. 2009;20: 1497-1502.

13. Rogers JV, Parkinson CV, Choi YW, Speshock JL, Hussain SM. A preliminary assessment of silver nanoparticle inhibition of monkeypox virus plaque formation. Nanoscale Research Letters. 2008;3:129-133.

14. Kim JS, Kuk E, Yu KN, et al. Antimicrobial effects of silver nanoparticles. Nanomedicine. 2007;3:95-101.

15. Baker C, Pradhan A, Pakstis L, et al. Synthesis and antibacterial properties of silver nanoparticles. J Nanosci Nanotechnol. 2005;5:244-249. 
16. Furno F, Morley KS, Wong B, et al. Silver nanoparticles and polymeric medical devices: A new approach to prevention of infection? JAntimicrob Chemother. 2004;54:1019-1024.

17. Rutberg FG, Dubina MV, Kolikov VA, et al. Effect of silver oxide nanoparticles on tumor growth in vivo. Dokl Biochem Biophys. 2008; 421:191-193.

18. Sondi I, Salopek-Sondi B. Silver nanoparticles as antimicrobial agent: A case study on E. coli as a model for Gram-negative bacteria. J Colloid Interface Sci. 2004;275:177-182.

19. Hu R, Yong KT, Roy I, et al. Metallic nanostructures as localized plasmon resonance enhanced scattering probes for multiplex dark field targeted imaging of cancer cells. J Phys Chem C Nanomater Interfaces. 2009;113:2676-2684.

20. Kemp MM, Kumar A, Mousa S, et al. Synthesis of gold and silver nanoparticles stabilized with glycosaminoglycans having distinctive biological activities. Biomacromolecules. 2009;10:589-595.

21. Arora S, Jain J, Rajwade JM, Paknikar KM. Cellular responses induced by silver nanoparticles: In vitro studies. Toxicol Lett. 2008;179:93-100.

22. Kumari A, Kumar P, Ajayan PM, John G. Silver-nanoparticle-embedded antimicrobial paints based on vegetable oil. Nat Mater. 2008;7: 236-241.

23. Dunn K, Edwards-Jones V. The role of Acticoat with nanocrystalline silver in the management of burns. Burns. 2004;30:S1-S9.

24. Kalishwaralal K, Banumathi E, Pandian SRK, et al. Silver nanoparticles inhibit VEGF induced cell proliferation and migration in bovine retinal endothelial cells. Colloid Surf B Biointerfaces. 2009;73: 51-57.

25. Sheikpranbabu S, Kalishwaralal K, Venkataraman D, Eom SH, Park J, Gurunathan S. Silver nanoparticles inhibit VEGF-and IL-1-induced vascular permeability via Src dependent pathway in porcine retinal endothelial cells. J Nanobiotechnology. 2009;7:8.

26. Sheikpranbabu S, Kalishwaralal K, Lee KJ, Vaidyanathan R, Eom SH, Gurunathan S. The inhibition of advanced glycation end-products-induced retinal vascular permeability by silver nanoparticles. Biomaterials. 2010;31:1318-1329.

27. Kalimuthu K, Pandian SRK, Deepak V, Bilal M, Gurunathan S. Biosynthesis of silver nanocrystals by Bacillus licheniformis. Colloid Surf B Biointerfaces. 2008;65:150-153.

28. Kalimuthu K, Pandian SRK, Deepak V, et al. Biosynthesis of silver and gold nanoparticles using Brevibacterium casei. Colloid Surf B Biointerfaces. 2010;1:77:257-262.
29. Gurunathan S, Kalishwaralal K, Vaidyanathan R, et al. Biosynthesis, purification and characterization of silver nanoparticles using Escherichia coli. Colloid Surf B Biointerfaces. 2009;74:328-335.

30. Khlebtsov NG. Determination of size and concentration of gold nanoparticles from extinction spectra. Anal Chem. 2008; 80:6620-6625.

31. Marquis BJ, Love SA, Braun KL, Haynes CL. Analytical methods to assess nanoparticle toxicity. Analyst. 2009;134:425-439.

32. Gurunathan S, Lee KJ, Kalimuthu K, Sheikpranbabu S, Vaidyanathan R, Eom SH. Anti angiogenic properties of silver nanoparticles. Biomaterials. 2009;30:6341-6350.

33. Martins D, Frungillo L, Anazzetti MC, Melo PS, Durán N. Antitumoral activity of L-ascorbic acid-poly- D,L-(lactide-co-glycolide) nanoparticles containing violacein. Int J Nanomedicine. 2010;5:77-85.

34. Kalishwaralal K, Banumathi E, Pandian SRK, Deepak V, Muniyandi J, Eom SH, Gurunathan S. Silver nanoparticles inhibit VEGF induced cell proliferation and migration in bovine retinal endothelial cells. Colloid Surf B Biointerfaces. 2009;73:51-57.

35. Blagoi, Yu P, Galkin VL, Gladchenko GO, et al. Metallokompleksy Nukleinovykh Kislot v Rastvorakh. [Metal Complexes of Nucleic Acids in Solutions]. Kiev: Naukova Dumka; 1991.

36. Arora S, Jain J, Rajwade JM, Paknikar KM. Cellular responses induced by silver nanoparticles: In vitro studies. Toxicol Lett. 2008;179:93-100.

37. Mendoza FJ, Espino PS, Cann KL, Bristow N, McCrea K, Los M. Antitumor chemotherapy utilizing peptide-based approaches - apoptotic pathways, kinases, and proteasome as targets. Arch Immunol Ther Exp. 2005;53:47-60

38. Nagy JA, Morgan ES, Herzberg KT, Manseau EJ, AM Dvorak, Dvorak HF. Pathogenesis of ascites tumor growth: Angiogenesis, vascular remodeling, and stroma formation in the peritoneal lining. Cancer Res. 1995;55:376-385.

39. Nagy JA, Masse EM, Herzberg KT, et al. Pathogenesis of ascites tumor growth: Vascular permeability factor, vascular hyperpermeability, and ascites fluid accumulation. Cancer Res. 1995;55:360-368.

40. Schmidt CW. Nanotechnology-related environment, health, and safety research. Environ Health Perspect. 2009;117:A158-A161.

41. Wagner V, Dullaart A, Bock AK, Zweck A. The emerging nanomedicine landscape. Nat Biotechnol. 2006;24:1211-1217.

42. Vaidyanathan R, Kalishwaralal K, Gopalram S, Gurunathan S. Nanosilver - the burgeoning therapeutic molecule and its green synthesis. Biotechnol Adv. 2009;27:924-937.
International Journal of Nanomedicine

\section{Publish your work in this journal}

The International Journal of Nanomedicine is an international, peerreviewed journal focusing on the application of nanotechnology in diagnostics, therapeutics, and drug delivery systems throughout the biomedical field. This journal is indexed on PubMed Central, MedLine, CAS, SciSearch ${ }^{\circledR}$, Current Contents ${ }^{\circledR} /$ Clinical Medicine,

\section{Dovepress}

Journal Citation Reports/Science Edition, EMBase, Scopus and the Elsevier Bibliographic databases. The manuscript management system is completely online and includes a very quick and fair peer-review system, which is all easy to use. Visit http://www.dovepress.com/ testimonials.php to read real quotes from published authors. 